\title{
Pyoderma gangrenosum among children in Senegal: 6 cases
}

\section{Boubacar Ahy Diatta, Fatou Fall Toumbou, Assane Diop, Saer Diadie, Maodo Ndiaye, Moussa Diallo, Suzanne Oumou Niang, Assane Kane, Mame Thierno Dieng}

Department of Dermatology, Cheikh Anta Diop University of Dakar, Dakar, Senegal

Corresponding author: Dr. Boubacar Ahy Diatta, E-mail: ahydiatta@yahoo.com

\begin{abstract}
The pyoderma gangrenosum (PG) is a chronic ulcerative neutrophilic dermatosis rare in children. It is often associated with chronic inflammatory bowel disease, some systemic diseases and leukemias. We report six cases in children. We collected six cases, the average age was 10 years ( $4-15$ years), the sex ratio was 0.16 ( 5 boys and 1 girl). The ulcerated clinical form of PG was noted in all children. The topography was in the lower limbs in five cases and in the cephalic extremity in three cases. The mean duration of evolution was 2 years ( 15 days-7 years). PG was associated with ulcerative colitis in one case. Oral corticosteroids were administered in all cases at a dose of 0.5 to $1 \mathrm{mg} / \mathrm{kg}$. The complete healing of the cutaneous lesions was obtained. Two children were lost to sight. Our study reports a male predominance of PG in children with ulcerative clinical form of the limb and association with ulcerative colitis. Corticosteroids appear to be efficient, but may be limited by their complications.
\end{abstract}

Key words: Pyoderma Gangrenosum; Children; Senegal

\section{INTRODUCTION}

Pyoderma gangrenosum (PG) is a chronic, recurrent ulcerative inflammatory disease that is part of the nosological framework of neutrophilic dermatoses. They are characterized by non-infectious infiltration of the skin by morphologically normal neutrophils $[1,2]$. It is often associated with chronic inflammatory bowel disease (IBD), some systemic diseases and to leukemias [1-4]. In tropical Africa the PG in children has been rarely reported and may be confusing with primitive bacterial dermatoses at this age. We report 6 cases.

\section{CASE REPORTS}

\section{Case 1}

A 12-year-old boy was received for ulcerations on the scalp after a period of evolution of 5 years. He was in poor health. The weight was $30 \mathrm{~kg}$, the size at $1.35 \mathrm{~m}$ and the temperature at $37.3^{\circ} \mathrm{C}$. Physical examination showed ulcerations with an irregular and atrophic border on the limbs and face. The complete blood cell count (CBC) showed neutrophil leukocytosis at 25.000/ $\mathrm{mm}^{3}, \mathrm{C}$ reactive protein at $48 \mathrm{mg} / \mathrm{l}$, anemia at $6 \mathrm{~g} / \mathrm{dl}$ and accelerated erythrocyte sedimentation rate (ESR). All infectious samples were sterile. The child received prednisone at $1 \mathrm{mg} / \mathrm{kg} /$ day and a blood transfusion. Complete scarring of skin lesions was noted at 6 months of follow-up. He had an obesity after 2 years of treatment.

\section{Case 2}

A 9-year-old boy was received for ulcers on the lower limbs after a period of evolution of 15 days. He was in poor health with temperature at $38,2^{\circ} \mathrm{C}$. The physical examination noted an ulcero-necrotic closet with infiltrated border, shredded of the lower limbs. Histology showed a non-specific polymorphic inflammatory infiltrate in dermis. Colonoscopy revealed a congestive and hemorrhagic rectocolitis.

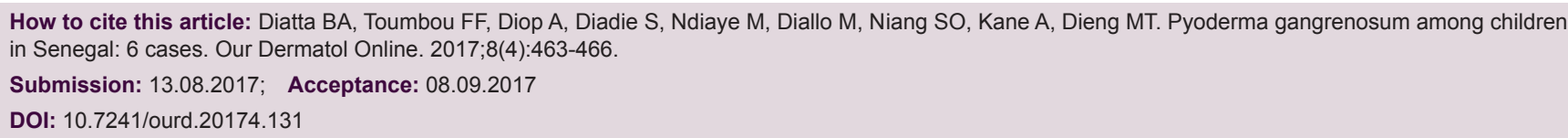


The CBC showed anemia at $3.9 \mathrm{~g} / \mathrm{dl}$, neutrophilic leukocytosis at $44000 / \mathrm{mm}^{3}, \mathrm{C}$-reactive protein at $92 \mathrm{mg} / \mathrm{l}$ and accelerated erythrocyte sedimentation rate. All infectious samples were sterile. He had received betametasone at $1 \mathrm{mg} / \mathrm{kg} /$ day and a blood transfusion. Complete scarring of the skin lesions was noted after a 7-month follow-up.

\section{Case 3}

A 15-year-old boy was received for ulcerations on the scalp and the leg after a period of evolution of 8 months. He was in poor health with and temperature at $36.2^{\circ} \mathrm{C}$. The physical examination noted an ulcerated helmet of the scalp overflowing on the frontal lobe and parietal lobes with an atrophic border. Histology was not contributory. The CBC showed neutrophilic leukocytosis at $12700 / \mathrm{mm}^{3}$, C-reactive protein at $192 \mathrm{mg} / \mathrm{l}$, anemia at $10.3 \mathrm{~g} / \mathrm{dl}$ and accelerated erythrocyte sedimentation rate. All infectious samples were sterile. He had received prednisone at $1 \mathrm{mg} / \mathrm{kg} / \mathrm{day}$. Healing of the skin lesions was noted at 3 months of follow-up and he was lost sight.

\section{Case 4}

A 10-year-old boy was received for ulcerations on the leg and the face after a period of evolution of 7 years. The physical examination showed an ulcerated cupboard on the leg and the face. The CBC noted anemia at $10 \mathrm{~g} / \mathrm{dl}$, neutrophilic leukocytosis at $11000 / \mathrm{mm}^{3}$, C-reactive protein at $48 \mathrm{mg} / \mathrm{l}$ and accelerated erythrocyte sedimentation rate. All infectious samples were sterile. He had received prednisone at $1.5 \mathrm{mg} / \mathrm{kg} /$ day. Full healing of the skin lesions was obtained after 12 months of follow-up. He presented obesity after 2 years of treatment.

\section{Case 5}

A 15-year-old girl was received for ulcerations of the leg after a period of evolution of one month. Physical examination noted ulcerous lesions with a purulent background at both legs (Figs. la and lb). Histology noted a dermal infiltrate of non-altered neutrophilic polynuclear in interstitial clusters between collagen fibers (Fig. 2). The CBC showed neutrophilic leukocytosis at $12000 / \mathrm{mm}^{3}$, C-reactive protein at $92 \mathrm{mg} / \mathrm{l}$ and accelerated erythrocyte sedimentation rate. All infectious samples were sterile. She received prednisone at $1 \mathrm{mg} / \mathrm{kg} /$ day. Healing of skin lesions

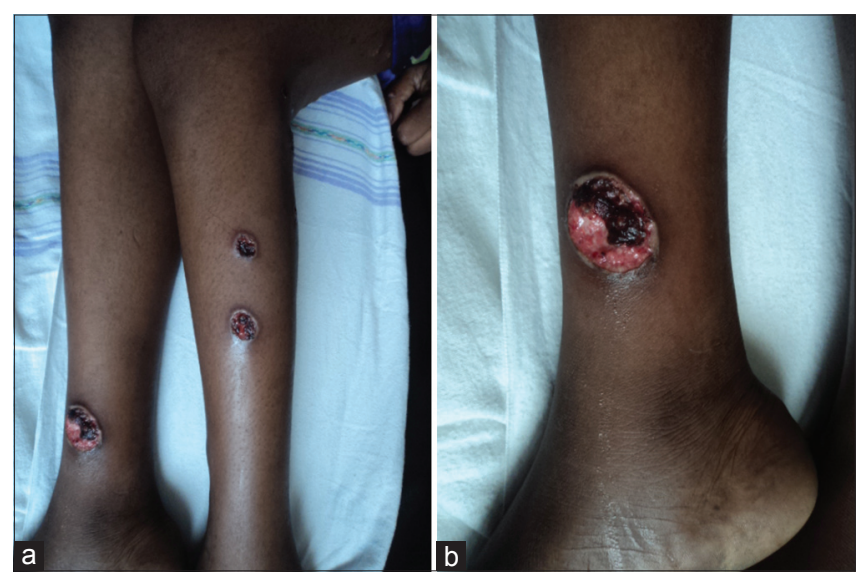

Figure 1: Multiple ulcers with infiltrated border of the leg.

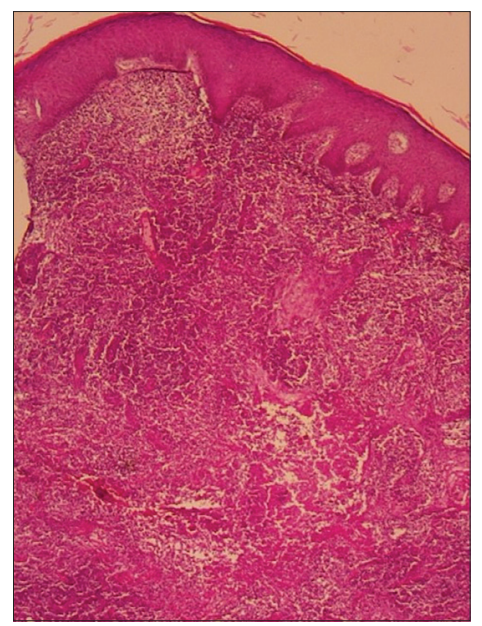

Figure 2: Dermal infiltrate of non-altered neutrophilic polynuclear in interstitial clusters between collagen fibers. HE X 100.

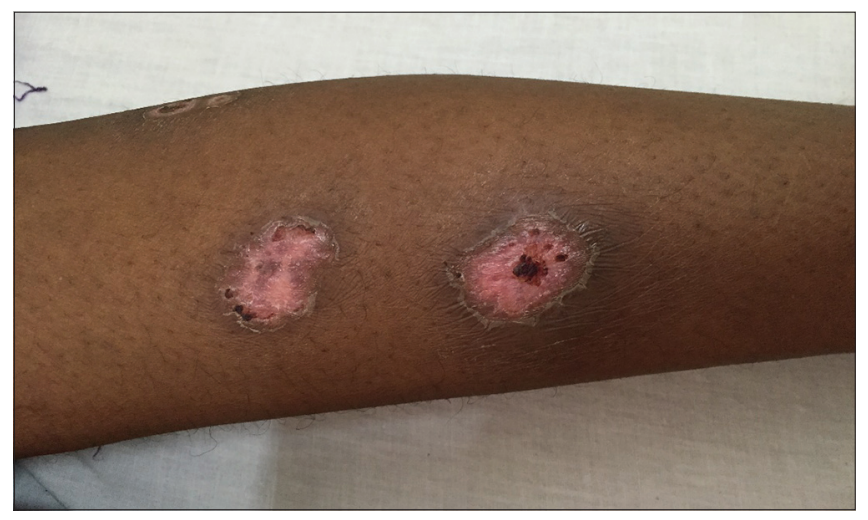

Figure 3: Ulcer healing at one week of corticosteroid therapy

(Fig. 3) was obtained after 12 months of follow-up and she was lost sight.

\section{Case 6}

A 4-year-old boy was received for diffuse cutaneous ulcerations of the leg and trunk after a period of 
Table I: Summary of cases

\begin{tabular}{|c|c|c|c|c|c|c|}
\hline & Case 1 & Case 2 & Case 3 & Case 4 & Case 5 & Case 6 \\
\hline Sex & $M$ & $M$ & $M$ & $M$ & $\mathrm{~F}$ & $M$ \\
\hline Age (years) & 12 & 9 & 15 & 10 & 15 & 4 \\
\hline $\mathrm{DE}$ & 5 years & 15 days & 8 months & 7 years & 1 month & 1 month \\
\hline Clinical form & Ulcer & Ulcer & Ulcer & Ulcer & Ulcer & Ulcer \\
\hline Topography & $\begin{array}{l}\text { Members } \\
\text { Head }\end{array}$ & Members & $\begin{array}{l}\text { Members } \\
\text { Head }\end{array}$ & $\begin{array}{l}\text { Members } \\
\text { Head }\end{array}$ & Members & Members \\
\hline Associated disease & None & UC & None & None & None & None \\
\hline Corticoïdes & Yes & Yes & Yes & Yes & Yes & Yes \\
\hline Healing & Yes & Yes & Yes & Yes & Yes & Yes \\
\hline Complications & Obesity & None & None & Obesity & None & None \\
\hline
\end{tabular}

DE: Duration of symptoms; UC: Ulcerative colitis; M: Male; F: Female

evolution of one month. He was in poor health with a fever at $39^{\circ} \mathrm{C}$. Physical examination showed rounded ulcerations on the trunk and lower limbs. The histology noted an infiltrate of polynuclear neutrophils of the dermis. The CBC showed neutrophilic leukocytosis at $20000 / \mathrm{mm}^{3}$, anemia at $7 \mathrm{~g} / \mathrm{dl}$, C-reactive protein at $92 \mathrm{mg} / \mathrm{l}$ and accelerated erythrocyte sedimentation rate. All infectious samples were sterile. He received prednisone at $1 \mathrm{mg} / \mathrm{kg} / \mathrm{day}$. Skin lesions were healed after 3 months of follow-up.

\section{DISCUSSION}

We reported six cases of pediatric PG with diagnosis based on semiological characteristics, histology in some cases, and leukocytosis without bacterial infections (Table 1). Our observations are remarkable for the delay in consultation, the difficulty of the diagnosis due to the diversity of the causes of cutaneous ulcerations in tropical pathology, the multiplicity of lesions, the cephalic localization and the constancy and severity of the anemia. These pediatric forms represent $30 \%$ of the PG in Dakar [3]. A delay in consultation was noted with an average duration of symptoms evolution of 2 years. This seems to be related to the inaccessibility of the population to specialized care and diagnostic wandering. The diagnosis of $\mathrm{PG}$ is essentially clinical. Other studies have proposed diagnostic criteria for PG, but he is stay still a diagnosis of exclusion [1,5-7]. The difficulty of the diagnosis is related to the clinical polymorphism and to the multiple causes of infantile cutaneous ulcerations in tropical pathology. The ulcerated clinical form was noted in all cases with a predominant topography in the lower limbs in $83 \%$. This may be related in part to minor trauma to the limbs at this age responsible for a pathergic phenomenon. The cephalic localization, also referred to as " malignant pyoderma ", was noted in three cases, and according to some authors it constitutes a particular aggressive form of ulcerative PG [4,6,8-10]. Histology had noted in our study a dermal neutrophilic infiltrate in $50 \%$ of cases. It allows an orientation towards a neutrophilic dermatoses and an anatomo-clinical confrontation. The etiology of pyoderma gangrenosum remains unknown [10]. Some etiological factors have been mentioned, notably genetic factors and an extrinsic or intrinsic anomaly of the neutrophilic polynuclear [1]. The association with ulcerative colitis is common in pediatric forms of PG [2,3]. General corticosteroids appear to be efficient as evidenced by the complete healing of ulcers in our cases. The prognosis depends on recurrences and corticosteroids complications associated with longterm treatment.

\section{CONCLUSION}

Our study confirms some known feature of PG among children in Senegal with a possible association with Inflammatory Bowel Diseases. The PG in children poses diagnostic problems because of the diversity of causes of cutaneous ulceration in tropical countries.

\section{RÉFÉRENCES}

1. Soutou B, Pennamen DV, Chosidow O. Les dermatoses neutrophiliques. Rev Med Int. 2011;32:306-13.

2. Ahmadi S, Powell FC. Pyoderma gangrenosum: presentations rares. Clin Dermatol. 2005;23:612-20.

3. Diallo M, Kane A, Sy N. Pyoderma gangrenosum à Dakar. A propos de 14 observations. Dakar Med. 2005;50:52-5.

4. Branes L. pustular pyoderma gangrenosum associated with colitis ulcerative in childhood. Report of 2 cases and review of the literature. J Am Dermatol. 1986;15:608.

5. Graham JA, Hansen KK, Rabinuwitz LG, Esterly NB. Pyoderma gangrenosum in infants and children. Pediatr Dermatol. 1994;11:10-7.

6. Nukumizu LA, Silva CA, Koda YK. Pyoderma gangrenosum maladies dans l'enfance et maladies associées systémiques: rapport de cinq cas. Rev Bras Rheumatol. 2002;42:65-71.

7. Champion RH,Burton JL, Burns DA. Pyoderma gangrenosum. 


\section{www.odermatol.com}

Rook/wilikinson Ebling Textbook of Dermatology. Boston, Mass: Blackwell; 1998: 2186-91.

8. Su WP, Davis MD, Weeding RH, Powell FC, Perry HO. Pyoderma gangrenosum: corrélation cliniques et proposition des critères diagnostiques. Int J Dermatol. 2004;43:790-800.

9. Reichrath J, Bens G, Bonowitz U, Tilgen W. Treatment recommendations for pyoderma gangrenosum: an evidence-based review of the literature based on more than 350 patients. J Am Acad Dermatol. 2005; 53:273-83.
10. Mlika RB, Riahi I, Fenniche S, Mokni M, Dhaoui MR, Dess N, et al. Pyoderma gangrenosum: a report of 21 cases. Int J Dermatol. 2002;41:65-8.

Copyright by Boubacar Ahy Diatta, et al. This is an open-access article distributed under the terms of the Creative Commons Attribution License, which permits unrestricted use, distribution, and reproduction in any medium, provided the original author and source are credited.

Source of Support: Nil, Conflict of Interest: None declared. 